\title{
PENGEMBANGAN MEDIA PEMBELAJARAN BERBASIS ANDROID DENGAN SISTEM APPY PIE PADA MATERI JURNAL PENYESUAIAN PERUSAHAAN JASA UNTUK KELAS XI IPS DI SMA NEGERI 2 JEMBER
}

\author{
Puspa Rosita Sari ${ }^{1}$, Sutrisno Djaja ${ }^{1}$, Sri Kantun ${ }^{1}$ \\ ${ }^{1}$ Program Studi Pendidikan Ekonomi, Fakultas Keguruan dan Ilmu Pendidikan, Universitas Jember \\ Jln. Kalimantan 37, Jember 68121 \\ E-mail: puspa.rositasari@gmail.com
}

\begin{abstract}
Abstrak
Penelitian ini bertujuan untuk mengembangkan media pembelajaran berbasis android dengan sistem $A P P Y$ PIE pada mata pelajaran ekonomi materi jurnal penyesuaian perusahaan jasa untuk siswa kelas XI IPS di SMA Negeri 2 Jember yang menarik, efisien, dan efektif. Penelitian menggunakan model pengembangan Four - D dari Thiagarajan et al yang terdiri dari tahap define, design, develope, disseminate. Kelayakan media dinilai melalui tahap validasi yang terdiri dari validasi isi materi, desain media, dan bahasa. Subjek uji coba pada penelitian ini yaitu uji kelompok terbatas pada 12 siswa XI IPS 2 dan uji kelompok lebih luas pada 30 siswa XI IPS 1. Instrumen pengumpulan data yang digunakan meliputi lembar validasi, angket, observasi, wawancara, dan dokumen. Teknik analisis data yang digunakan adalah uji tingkat daya tarik media, tingkat efisiensi, dan efektivitas media. Hasil penelitian menunjukkan bahwa media yang dikembangkan lebih menarik, tingkat daya tarik pada uji kelompok terbatas adalah 89,39\% (sangat menarik) dan pada uji kelompok lebih luas adalah $92,60 \%$ (sangat menarik). Media yang dikembangkan juga lebih efisien, pada uji kelompok terbatas dan uji kelompok lebih luas diketahui bahwa dengan menggunakan media berbasis android waktu lebih singkat yaitu dari 8 jam pelajaran menjadi 6 jam pelajaran. Media yang dikembangkan juga lebih efektif karena dapat mencapai tujuan pembelajaran, terjadi peningkatkan hasil belajar siswa pada uji kelompok terbatas dari 79,67 meningkat menjadi 86,83, pada uji kelompok lebih luas dari 80,97 meningkat menjadi 87,03 . Hasil dari penelitian pengembangan ini adalah media pembelajaran yang dikembangkan lebih menarik, lebih efisien, dan lebih efektif dari media sebelumnya.
\end{abstract}

Kata Kunci: Pengembangan, Media Pembelajaran Berbasis Android dengan Sistem APPY PIE, Jurnal Penyesuaian

\section{PENDAHULUAN}

Proses pembelajaran sesuai dengan kurikulum 2013 adalah proses pembelajaran yang mengintegrasikan Teknologi Informasi dan Komunikasi (TIK). TIK memiliki peran penting dalam proses pembelajaran, salah satunya yaitu dimanfaatkan untuk media pembelajaran. Menurut Kemp et.al (dalam Uno dan Nina, 2011: 124) melalui media pembelajaran berbasis TIK materi akan ditampilkan lebih ringkas, kegiatan pembelajaran lebih menarik, lebih interaktif, waktu yang dibutuhkan untuk menyampaikan materi lebih sedikit, dapat digunakan dimana saja, serta mampu menunjukkan sikap positif siswa dalam proses pembelajaran lebih baik lagi.

Media pembelajaran berbasis TIK di SMA Negeri 2 Jember untuk mata pelajaran ekonomi materi jurnal penyesuaian perusahaan jasa belum menarik, efisien, dan efektif karena masih berupa powerpoint. Berdasarkan informasi dari guru mata pelajaran ekonomi kelas XI IPS di SMA Negeri 2 Jember, media powerpoint yang digunakan oleh guru dilihat dari segi tampilan media tersebut belum menarik. Dilihat dari efisiensi waktu yang digunakan oleh guru untuk menjelaskan materi jurnal penyesuaian dengan media powerpoint melebihi jam pelajaran yang telah ditentukan yaitu lebih dari 8 jam pelajaran. Media tersebut juga belum efektif dilihat dari rata - rata hasil belajar siswa yang masih rendah yaitu 78 .

Kondisi diatas menunjukkan bahwa perlu adanya pengembangan media pembelajaran berbasis TIK yang lebih menarik, lebih efisien, dan lebih efektif yaitu dengan mengembangkan media pembelajaran berbasis android dengan sistem APPY PIE. Menurut Irsyad (2016:67) APPY PIE merupakan salah satu online app builder yang menyediakan layanan gratis untuk merancang aplikasi 
pendidikan pada smartphone. Media pembelajaran berbasis android merupakan media yang memanfaatkan smartphone, mengingat karakteristik siswa jaman sekarang yang tidak bisa lepas dari smartphone. Tidak hanya guru yang menggunakan media tersebut tetapi siswa juga menggunakan. Masing - masing siswa harus melakukan proses instal terlebih dahulu untuk dapat menggunakan aplikasi. Proses instal bisa dilakukan dengan mudah, guru cukup membagikan link download kemudian siswa mengunduh dan mengikuti alur untuk menginstal. Media pembelajaran berbasis android dengan sistem APPY PIE dirancang dalam satu aplikasi yang memuat materi jurnal penyesuaian perusahaan jasa secara rinci yang disertai dengan video tutorial pencatatan jurnal penyesuaian, contoh soal, hingga kuis untuk latihan siswa dan bahasa yang digunakan dalam media ini menggunakan bahasa yang baku sehingga mudah dipahami oleh siswa. Hal tersebut sejalan dengan pendapat Deni (2005: 102) bahwa media pembelajaran berbasis TIK yang inovatif dapat menumbuhkan semangat belajar siswa, proses pembelajaran menjadi efisien, dan mampu meningkatkan pemahaman siswa. Media tersebut juga memiliki beberapa kelebihan diantaranya dapat digunakan dimana saja, mampu meningkatkan interaksi antara guru dan siswa, bisa digunakan untuk belajar mandiri, dan sebagainya.

Media pembelajaran berbasis TIK yang menarik menurut Jalinus dan Ambiyar (2016:19) harus memiliki karakteristik memberikan kemudahan untuk mengakses bagi pengguna, memanfaatkan unsur teknologi, dan merupakan salah satu media yang baru dengan tampilan - tampilan yang menarik. Media pembelajaran yang menarik ditunjukkan melalui tampilan media yang dikemas dengan desain yang baru dan menarik. Media pembelajaran yang menarik akan memudahkan siswa untuk memahami materi, sehingga media tersebut juga dapat meningkatkan efisiensi proses pembelajaran. Media pembelajaran berbasis TIK yang efisien menurut Musfiqon (2012:116) harus memuat unsur biaya, waktu, dan sumber daya yang lain seminimal mungkin untuk dapat mencapai tujuan pembelajaran yang diinginkan. Selanjutnya media dikatakan efektif menurut Uno (2008: 21) apabila tujuan pembelajaran bisa tercapai. Efektivitas media pembelajaran ditunjukkan dengan adanya peningkatan hasil belajar siswa setelah menggunakan media pembelajaran yang dikembangkan.

Berdasarkan gambaran tersebut, maka peneliti mengembangkan media pembelajaran yang lebih menarik, lebih efisien, dan lebih efektif yaitu media pembelajaran berbasis android dengan sistem $A P P Y$ PIE pada mata pelajaran ekonomi materi jurnal penyesuaian perusahaan jasa untuk siswa kelas XI IPS di SMA Negeri 2 Jember

\section{METODE}

Penelitian ini merupakan penelitian pengembangan yang menggunakan model pengembangan Four - D dari Thiagarajan et al (1974:1) yang terdiri dari tahap define (pendefinisian), design (perancangan), develope (pengembangan) dan disseminate (penyebaran). Namun, dalam penelitian ini hanya dibatasi sampai pada tahap pengembangan saja. Penilaian kelayakan terhadap media pembelajaran yang dikembangkan diketahui melalui hasil penilaian tim validator yang terdiri dari validasi isi materi pada media, validasi desain media, dan validasi bahasa. Subjek uji coba produk meliputi uji kelompok terbatas pada kelas XI IPS 2 SMA Negeri 2 Jember dengan jumlah 12 siswa dan uji kelompok lebih luas XI IPS 1 SMA Negeri 2 Jember dengan jumlah 31 siswa. Teknik analisis data yang digunakan dalam penelitian pengembangan ini yaitu uji tingkat daya tarik yang diketahui dengan cara menyebarkan angket pada siswa kemudian menghitungnya dengan cara menskore, uji efisiensi dapat diketahui melalui wawancara dengan guru pengampu mata pelajaran ekonomi kelas XI IPS di SMA Negeri 2 Jember, serta uji efektivitas diketahui dengan cara membandingkan nilai rata rata sebelum dan sesudah penggunaan media pembelajaran berbasis android dengan sistem APPY PIE menggunakan program SPSS 22.0 for windows dengan uji t-test.

\section{HASIL DAN PEMBAHASAN Hasil Pengembangan}

Penelitian pengembangan ini untuk mengetahui tingkat daya tarik, efisiensi, dan efektivitas media pembelajaran yang dikembangkan melalui uji coba produk. Sebelum menilai tingkat kemenarikan, 
efisiensi, dan efektivitas media pembelajaran yang dikembangkan maka dilakukan validasi ahli terlebih dahulu.

Berdasarkan kegiatan penilaian terhadap media yang dikembangkan yang telah dilakukan peneliti, maka diperoleh skor penilaian terhadap isi materi pada media tahap I sebesar 77,5\% dalam kategori layak tetapi masih ada revisi. Terdapat beberapa komponen yang masih harus direvisi yaitu uraian materi harus disertai dengan contoh, soal uraian dan kuis interaktif dikurangi agar proses pembelajaran lebih efisien. Hasil penilaian isi materi pada media tahap II sebesar 95\% dalam kategori sangat layak.

Hasil penilaian desain media tahap I sebesar 78\% dalam kategori layak tetapi masih ada revisi. Terdapat beberapa komponen yang masih harus diperbaiki yaitu nama aplikasi, tampilan awal media, ikon menu pada media, serta background media. Selanjutnya dilakukan penilaian tahap II diperoleh skor $98 \%$ dalam kategori sangat layak.

Hasil penilaian bahasa yang digunakan pada media tahap I diperoleh skor 76,67\% dalam kategori layak namun masih perlu revisi. Terdapat 3 hal yang perlu diperbaiki yaitu konsistensi penggunaan kata, penulisan istilah asing, serta penggunaan bahasa yang kurang komunikatif. Selanjutnya penilaian bahasa pada tahap II diperoleh skor 93,34\% dalam kategori sangat layak.

Hasil penilaian tahap II yang dilakukan oleh semua tim validator menunjukkan bahwa media pembelajaran yang dikembangkan dalam kategori sangat layak diujicobakan tanpa adanya revisi. Penilaian terhadap media dilakukan oleh validator dan juga siswa sehingga langkah selanjutnya yaitu pelaksanaan uji coba pada kelompok terbatas dan kelompok lebih luas untuk mengetahui kemenarikan, efisiensi, dan efektivitas produk yang dikembangkan. Berikut ini uraian hasil uji coba kelompok terbatas dan kelompok lebih luas yang dilihat dari kemenarikan, keefisienan, dan keefektifan media pembelajaran yang dikembangkan:

1) Kemenarikan Media Pembelajaran Berbasis Android dengan Sistem APPY PIE

Tingkat daya tarik media pembelajaran berbasis android dengan sistem APPY PIE dapat dilihat dari angket respon siswa. Berikut ini tabel perolehan skor pada setiap indikator dalam angket pada uji coba kelompok terbatas dan kelompok lebih luas:

Tabel 1. Respon Siswa Terhadap Daya Tarik Media

\begin{tabular}{lllcl}
\hline \multirow{2}{*}{ No } & \multicolumn{1}{c}{ Indikator } & \multicolumn{2}{c}{ Perolehan Skor } & Kategori \\
\cline { 3 - 4 } & \multicolumn{1}{c}{$\begin{array}{c}\text { Kelompok } \\
\text { Terbatas }\end{array}$} & $\begin{array}{c}\text { Kelompok } \\
\text { Lebih Luas }\end{array}$ & \\
\hline 1 & $\begin{array}{l}\text { Media pembelajaran berbasis android } \\
\text { untuk mata pelajaran ekonomi dapat } \\
\text { diinstal dengan mudah }\end{array}$ & $83,33 \%$ & $93,5 \%$ & Sangat Menarik \\
\hline 2 & $\begin{array}{l}\text { Materi pada media pembelajaran } \\
\text { berbasis android dikemas dengan } \\
\text { menarik }\end{array}$ & $91,67 \%$ & $96,7 \%$ & Sangat Menarik \\
\hline 3 & $\begin{array}{l}\text { Media pembelajaran berbasis android } \\
\text { ini menggunakan bahasa komunikatif } \\
\text { dan mudah dimengerti }\end{array}$ & $91,67 \%$ & $87 \%$ & Sangat Menarik \\
\hline 4 & $\begin{array}{l}\text { Media pembelajaran ini mampu } \\
\text { menumbuhkan motivasi untuk belajar } \\
\text { ekonomi }\end{array}$ & $91,67 \%$ & $96,7 \%$ & Sangat Menarik \\
\hline 5 & $\begin{array}{l}\text { Media pembelajaran android ini } \\
\text { membantu untuk menambah } \\
\text { pemahaman tentang materi akuntansi }\end{array}$ & $91,67 \%$ & $83,8 \%$ & Sangat Menarik \\
\hline 6 & $\begin{array}{l}\text { Media pembelajaran berbasis android } \\
100 \%\end{array}$ & $96,7 \%$ & Sangat Menarik \\
\hline
\end{tabular}




\begin{tabular}{lllll}
\hline \multicolumn{3}{c}{$\begin{array}{l}\text { ini menjadikan suasana belajar lebih } \\
\text { menyenangkan }\end{array}$} & & \\
\hline 7 & $\begin{array}{l}\text { Menumbuhkan rasa ingin tau yang } \\
\text { tinggi terhadap materi akuntansi }\end{array}$ & $83,33 \%$ & $87 \%$ & Sangat Menarik \\
\hline 8 & $\begin{array}{l}\text { Media pembelajaran berbasis android } \\
\text { dapat dipelajari secara mandiri }\end{array}$ & $100 \%$ & $100 \%$ & Sangat Menarik \\
\hline 9 & $\begin{array}{l}\text { Media pembelajaran android ini } \\
\text { lebih menyenangkan dibandingkan } \\
\text { dengan menggunakan powerpoint }\end{array}$ & $83,33 \%$ & $93,5 \%$ & Sangat Menarik \\
\hline 10 & $\begin{array}{l}\text { Media pembelajaran ini termasuk } \\
\text { media yang kreatif dan inovatif }\end{array}$ & $91,67 \%$ & $100 \%$ & Sangat Menarik \\
\hline 11 & $\begin{array}{l}\text { Android yang digunakan tidak hang } \\
\text { (berhenti) ketika aplikasi media } \\
\text { pembelajaran ini berjalan }\end{array}$ & $75 \%$ & $83,8 \%$ & Sangat Menarik \\
\hline & $\quad$ Rata - rata
\end{tabular}

Data Primer yang diolah, 2019

Tabel diatas menunjukkan tingkat daya tarik media pembelajaran berbasis android dengan sistem APPY PIE uji kelompok terbatas dan kelompok lebih luas. Pada uji kelompok terbatas diperoleh rata - rata presentase sebesar 89,39\% dengan kategori sangat menarik. Selanjutnya pada uji coba kelompok lebih luas diperoleh skor sebesar 92,60\% dengan kategori sangat menarik. Hasil dari kedua uji coba tersebut menunjukkan bahwa media pembelajaran yang dikembangkan dalam kategori sangat menarik.

2) Efisiensi Media Pembelajaran Berbasis Android dengan Sistem APPY PIE

Efisiensi media pembelajaran yang dikembangkan dapat dilihat dari alokasi waktu yang digunakan pada saat proses pembelajaran menggunakan media pembelajaran berbasis android dengan sistem APPY PIE. Efisiensi media pembelajaran berbasis android dengan sistem APPY PIE dapat dilihat pada subjek uji coba kelompok terbatas dan kelompok lebih luas. Berdasarkan informasi guru mata pelajaran ekonomi kelas XI IPS di SMA Negeri 2 Jember pada uji coba kelompok terbatas diketahui alokasi waktu yang dibutuhkan dalam kegiatan pembelajaran yaitu 6 jam pelajaran sedangkan waktu yang ditentukan yaitu 8 jam pelajaran. Pada saat uji kelompok lebih luas alokasi waktu yang digunakan juga sama, hanya memerlukan waktu 6 jam pelajaran. Hal ini didukung dengan wawancara yang dilakukan oleh peneliti kepada guru mata pelajaran ekonomi dan juga salah satu siswa kelas XI IPS.

" Alokasi waktu yang telah ditentukan untuk mempelajari materi jurnal penyesuaian perusahaan jasa 8 jam pelajaran. Ternyata dengan menggunakan media pembelajaran berbasis android, materi jurnal penyesuaian dapat diselesaikan lebih cepat, hanya memerlukan 6 jam pelajaran siswa sudah paham dan mampu mengerjakan soal dengan baik. Sehingga waktu yang tersisa bisa dimanfaatkan untuk latihan soal maupun pengayaan agar siswa paham secara maksimal." (L, 51 tahun)

Berdasarkan hasil wawancara yang dilakukan dengan guru mata pelajaran ekonomi dapat disimpulkan bahwa media pembelajaran berbasis android dengan sistem APPY PIE yang dikembangkan dikatakan efisien untuk digunakan dalam proses pembelajaran ekonomi materi jurnal penyesuaian perusahaan jasa dengan alokasi waktu yang dibutuhkan kurang dari alokasi waktu yang telah ditentukan berdasarkan silabus. Alokasi waktu yang dibutuhkan hanya 6 jam pelajaran sedangkan alokasi waktu yang ditentukan 8 jam pelajaran.

3) Efektivitas Media Pembelajaran Berbasis Android dengan Sistem APPY PIE 
Tingkat efektivitas media pembelajaran berbasis android dengan sistem APPY PIE pada uji kelompok terbatas dan kelompok lebih luas dapat diketahui dari perbandingan rata - rata nilai siswa sebelum dan sesudah penggunaan media pembelajaran berbasis android. Berikut ini merupakan distribusi nilai ulangan harian siswa sebelum dan sesudah penggunaan media pembelajaran berbasis android dengan sistem APPY PIE pada kelompok terbatas:

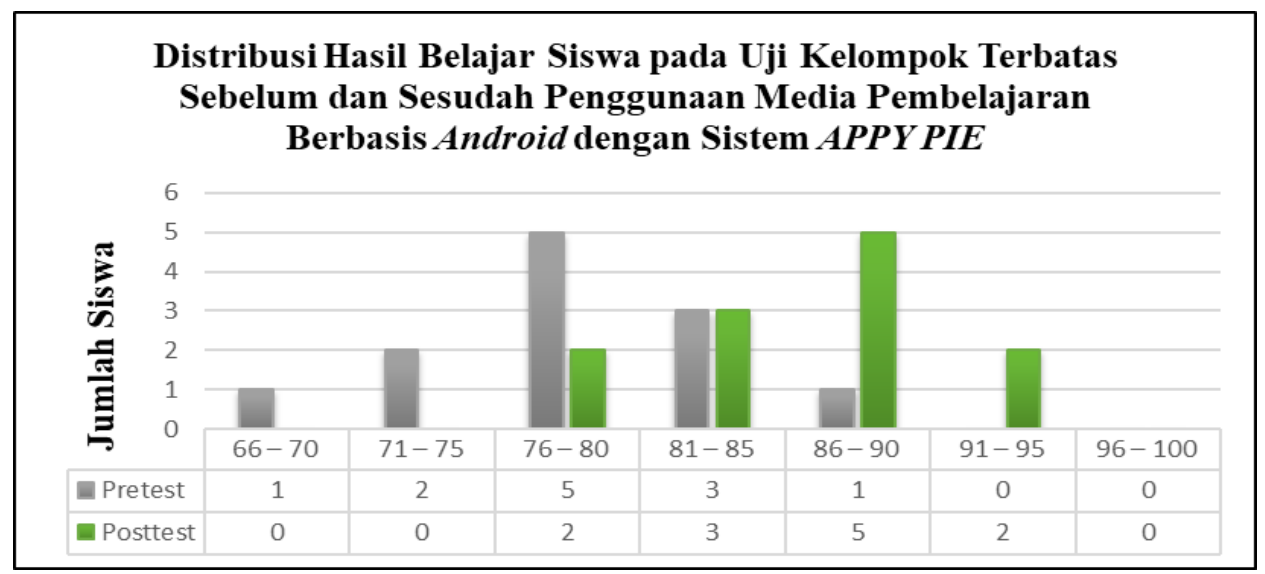

Diagram 1. Distribusi Nilai pada Kelompok Terbatas

Dari distribusi nilai diatas kemudian dianalisis dengan menggunakan SPSS versi 22 dengan uji $\mathrm{t}$ - test sebagai berikut:

Tabel 2. Hasil Statistik dengan Sampel Berpasangan pada Uji Kelompok Terbatas Paired Samples Statistics

\begin{tabular}{|ll|r|r|r|r|}
\hline & & Mean & N & Std. Deviation & Std. Error Mean \\
\hline Pair 1 & Pretest & 79.67 & 12 & 5.193 & 1.499 \\
& Post test & 86.83 & 12 & 4.549 & 1.313 \\
\hline
\end{tabular}

Berdasarkan keterangan yang ada pada tabel dapat diketahui bahwa terdapat peningkatan rata rata hasil belajar siswa sebelum dan sesudah penggunaan media pembelajaran berbasis android dengan sistem APPY PIE, dari 79,67 meningkat menjadi 86,83.

Sedangkan distribusi hasil belajar siswa sebelum dan sesudah penggunaan media pembelajaran berbasis android dengan sistem APPY PIE pada kelompok lebih luas yaitu:

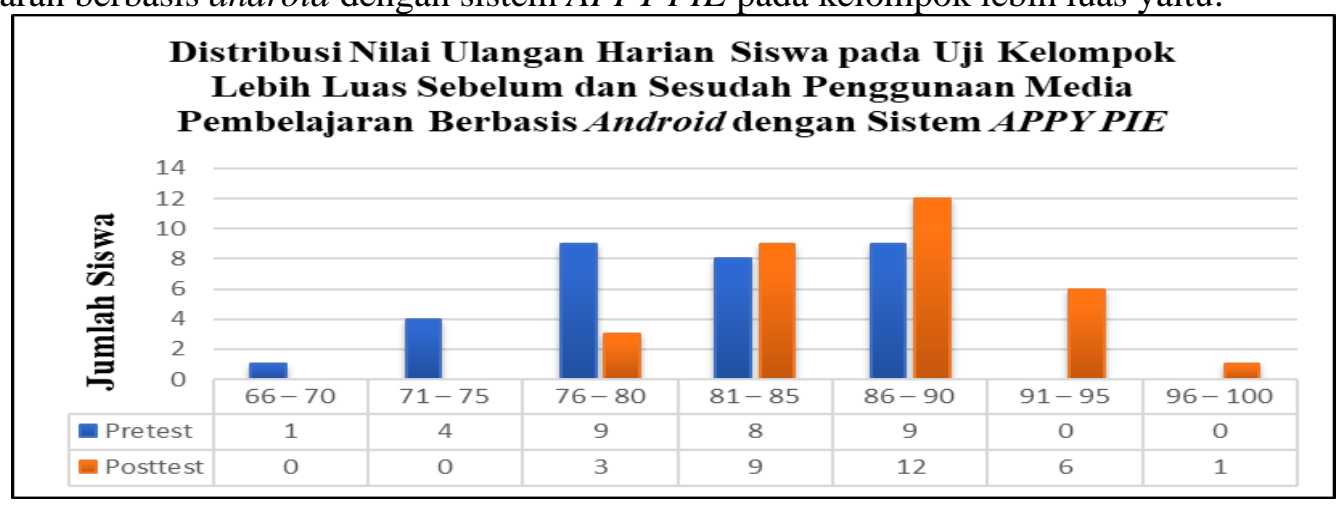

Diagram 2. Distribusi Nilai pada Kelompok Terbatas 
Dari distribusi nilai diatas kemudian dianalisis dengan menggunakan SPSS versi 22 dengan uji $\mathrm{t}$ - test sebagai berikut:

Tabel 3. Hasil Statistik dengan Sampel Berpasangan pada Uji Kelompok Lebih Luas

Paired Samples Statistics

\begin{tabular}{|ll|r|r|r|r|}
\hline & \multicolumn{1}{|c|}{ Mean } & N & Std. Deviation & \multicolumn{1}{c|}{ Std. Error Mean } \\
\hline Pair 1 & Pretest & 80.97 & 31 & 5.218 & .937 \\
& Post test & 87.03 & 31 & 4.317 & .775 \\
\hline
\end{tabular}

Berdasarkan keterangan yang ada pada tabel dapat diketahui bahwa terdapat peningkatan rata rata hasil belajar siswa sebelum dan sesudah penggunaan media pembelajaran berbasis android dengan sistem APPY PIE, dari 80,97 meningkat menjadi 87,03. Sehingga media pembelajaran berbasis android dengan sistem APPY PIE merupakan media yang efektif karena mampu menunjukkan peningkatan hasil belajar siswa pada uji kelompok terbatas maupun pada kelompok lebih luas.

\section{Pembahasan Hasil Pengembangan}

Hasil dari penelitian pengembangan ini adalah media pembelajaran berbasis android dengan sistem APPY PIE pada materi jurnal penyesuaian perusahaan jasa untuk kelas XI IPS di SMA Negeri 2 Jember yang lebih menarik, efisien, dan efektif. Kemenarikan media pembelajaran yang dikembangkan dilihat melalui hasil angket respon siswa yang menunjukkan kategori sangat menarik. Menurut Rusman (2013: 173) media pembelajaran berbasis teknologi yang menarik merupakan media pembelajaran yang menumbukan rasa ingin tahu siswa, mendorong siswa untuk lebih semangat dalam belajar dan bisa belajar secara mandiri.

Efisiensi dapat dilihat dari alokasi waktu yang digunakan untuk menyampaikan materi jurnal penyesuaian perusahaan jasa menggunakan media pembelajaran berbasis android dengan sistem APPY $P I E$. Berdasarkan wawancara yang dilakukan dengan guru pengampu mata pelajaran ekonomi waktu yang diperlukan untuk mempelajari materi menyusun jurnal penyesuaian perusahaan jasa dengan media pembelajaran berbasis android dengan sistem APPY PIE lebih singkat dari 8 jam pelajaran menjadi 6 jam pelajaran saja, baik pada saat uji kelompok terbatas maupun pada uji kelompok lebih luas. Sesuai dengan pendapat Rusman (2017:221) dengan menggunakan media pembelajaran berbasis android, proses persiapan dan penggunaannya membutuhkan waktu yang relatif singkat. Sehingga dapat dikatakan bahwa media pembelajaran berbasis android yang dikembangkan dikatakan efisien.

Efektivitas media pembelajaran berbasis android dengan sistem APPY PIE dapat diketahui dari perbedaan rata - rata hasil belajar siswa sebelum dan sesudah menggunakan media pembelajaran berbasis android pada materi menyusun jurnal penyesuaian perusahaan jasa. Perbedaan tersebut menunjukkan bahwa rata - rata hasil belajar siswa dengan menggunakan media pembelajaran berbasis android dengan sistem APPY PIE lebih tinggi daripada hasil belajar siswa sebelum menggunakan media pembelajaran yang dikembangkan oleh peneliti. Sesuai dengan pendapat Jalinus dan Ambiyar (2016:4) apabila media pembelajaran berbasis android dengan sistem APPY PIE yang digunakan dapat membantu proses pembelajaran dan kesesuaian untuk mewujudkan tujuan pembelajaran, maka media pembelajaran dapat dikatakan efektif. Hal tersebut menunjukkan bahwa media pembelajaran berbasis android dengan sistem APPY PIE yang dihasilkan merupakan media pembelajaran yang efektif untuk digunakan pada pelajaran ekonomi materi menyusun jurnal penyesuaian perusahaan jasa.

\section{PENUTUP}

Produk yang dihasilkan dalam penelitian pengembangan ini yaitu media pembelajaran berbasis android dengan sistem APPY PIE berupa aplikasi digital, sehingga hanya dengan menginstal aplikasi di smartphone siswa sudah bisa mempelajari materi yang terangkum dalam satu aplikasi. Adapun kelebihan dari media pembelajaran berbasis android dengan sistes APPY PIE pada materi menyusun jurnal penyesuaian perusahaan jasa sebagai berikut:

a. Media pembelajaran berbasis android dengan sistem APPY PIE disusun sesuai dengan kebutuhan dan karakteristik siswa kelas XI IPS SMA Negeri 2 Jember pada materi menyusun jurnal 
penyesuaian perusahaan jasa sehingga memudahkan siswa dalam memahami materi yang disampaikan dan dapat mencapai tujuan pembelajaran yang diharapkan.

b. Desain media disusuk semenarik mungkin dengan pemilihan warna yang menarik, tata letak yang tepat, serta pemilihan gambar - gambar ikon yang menarik.

c. Proses pembagian atau penyebarannya mudah, bisa melalui transfer file seperti bluetooth maupun share it. Selain itu juga bisa melalui pelayanan message seperti email, whatsaap, facebook maupun melalui link yang dibagikan.

d. Ada unsur audio visual sehingga lebih menarik perhatian siswa, seperti video pembelajaran. Selain itu juga ada kuis interaktif yang berguna untuk mengasah kecepatan dan ketepatan siswa dalam menyelesaikan tugasnya.

Adapun kelemahan dari media pembelajaran berbasis android dengan sistem APPY PIE yang telah dikembangkan yaitu: (1) Terbatas pada mata pelajaran ekonomi materi menyusun jurnal penyesuaian perusahaan jasa yang digunakan untuk siswa kelas XI IPS SMA Negeri 2 Jember, (2) pembuatannya memerlukan waktu yang relatif lama dan bergantung pada koneksi internet.

Berdasarkan pada penelitian pengembangan yang telah dilakukan terdapat beberapa saran yaitu saran pemanfaatan produk dimana sekolah yang menggunakan produk ini harus menyediakan fasilitas penunjang berupa koneksi internet yang lancar, membaca petunjuk penggunaan sebelum menggunakan, serta mengerjakan seluruh perintah untuk meningkatkan pemahaman. Saran diseminasi produk yaitu dengan cara menyebarkan produk pengembangan ini secara online melalui google play sehingga bisa diakses oleh banyak pengguna. Saran pengembangan lebih lanjut yaitu dapat disebarluaskan pada sekolah lain dan tidak terbatas pada materi jurnal penyesuaian perusahaan jasa.

\section{DAFTAR PUSTAKA}

Deni, Hardianto. 2005. Media Pendidikan sebagai Sarana Pembelajaran yang Efektif. Majalah Ilmiah Pembelajaran 1, Vol. 1. Hlm 95-104.

Irsyad, Hanif. 2016. Aplikasi Android dalam 5 Menit. Jakarta: Elex Media Komputindo.

Jalinus, Nizwardi dan Ambiyar. 2016. Media dan Sumber Belajar. Jakarta: Kencana.

Musfiqon. 2012. Pengembangan Media dan Sumber Pembelajaran. Jakarta: PT Prestasi Pustakaraya.

Rusman. 2013. Belajar dan Pembelajaran Berbasis Komputer. Bandung: Alfabeta.

Rusman. 2017. Belajar dan Pembelajaran Berorientasi Standar Proses Pendidikan. Jakarta: Kencana.

Thiagarajan, S., Semmel, D. S, \& Semmel, M. I. 1974. Instructional Developmentfor Training Teacher of Expectional Children. Minneapolis: Leadership Training Institute.

Uno, Hamzah B. 2008. Model Pembelajaran. Jakarta: Bumi Aksara.

Uno, Hamzah B, dan Nina, Lamatenggo. 2011. Teknologi Komunikasi dan Informasi Pembelajaran. Jakarta: Bumi Aksara. 